\title{
The Effect of Biochar, Lime, and Compost on The Properties of Acid Sulphate Soil
}

\author{
JUHRIAN $^{*}$, FADLY H. YUSRAN ${ }^{2}$, RAIHANI WAHDAH ${ }^{3}$, BAMBANG J. PRIATMADI ${ }^{2}$ \\ ${ }^{1}$ Graduate School of Lambung Mangkurat University, Banjarbaru (70714), Indonesia \\ ${ }^{2}$ Soil Science Department, Faculty of Agriculture, Lambung Mangkurat University, Banjarbaru (70714), \\ Indonesia \\ ${ }^{3}$ Agronomy Study Program, Lambung Mangkurat University, Banjarbaru (70714), Indonesia
}

\begin{abstract}
Making acid sulphate soils as paddy fields is a wise choice because it can prevent the soil from oxidizing which occurs in acidification of the soil. The use of biochar as an amendment to the land has long been known since the discovery of terra preta since 1870 in the Amazon Basin as the Amazon dark earth. Because biochar soil amendments are rich in C-organics, have a buffering capacity and can increase soil acidity, are able to absorb heavy metals, and are able to retain water and nutrients for soil organisms. Meanwhile, lime has also been known as an acid sulphate soil amendment in Rome 2000 years ago to balance the acidity in agricultural land. This has been practiced for centuries until now. Though compost or organic soil can be traced more than 2000 years ago. Soil organic matter (SOM) is formed from the remains of animals and plants. It contains $\mathrm{C}$ and many nutrients such as $\mathrm{N}$, P, and $\mathrm{K}$. Based on the description above, the author wants to combine the three ingredients in the review, especially in relation to acid sulphate soils.
\end{abstract}

Keywords: Biochar, lime, compost, acid sulphate soil

\section{ACID SULPHATE SOIL}

Indonesia has significant potential for swamp agricultural development now and in the future, but its utilization is not yet optimal (Ah \& Nursyamsi, 2015). Acidic soils in Indonesia are spread between large islands, such as Kalimantan (39.42\%), Sumatra (28.81\%), Papua (18.03\%), Java (7.77\%), and Sulawesi $(6.95 \%)$ (Hartatik, 2010; Masulili, 2010; Arsyad et al., 2014; (Ah \& Nursyamsi, 2015; Masulili, 2015; Berek, 2019). Most of them derived from volcanic rocks and old sediments under humid tropical conditions and are dominated by the Ultisols (41.92\%), Inceptisols (40.89\%), Oxisols (14.14\%), Entisols (3.8\%), and Spodosols (2.08\%) (Muhrizal Sarwani, 2013; Berek, 2019). The total area of acid sulphate that has been utilized in South Kalimantan is 182,990 ha, with an area of 99,695 ha located in Barito Kuala District but only 78,209 ha have been cultivated as agricultural land Correspondence: Juhrian; Graduate School of Lambung Mangkurat University, Banjarbaru (70714), Indonesia. Email: juhrian@mhs.ulm.ac.id

Journal of Wetlands Environmental Management

Vol. 8, No 2 (2020) 129-140

http://dx.doi.org/10.20527/jwem.v8il.200
(UNICEF, 2013; Rina \& Haris, 2013; Muhammad Alwi, 2014).

Acid sulphate soils, generally have low Pavailability due to the large fixation by $\mathrm{Al}$, and Fe (Dent, 1986; Saleh, 2017). Some rice fields are located in these areas of soil, which not only have low $\mathrm{pH}$ levels $(<3.5)$, but also contain high $\mathrm{Al}$ and $\mathrm{Fe}$ (Shazana et al., 2014). Making acid sulphate soils as rice field is a wise choice because it can prevent soil from oxidation which is soil acidification process (Eka Bhakari \& Hanum, 2013). Sulfuric acid in soil and sediment is formed naturally in waterlogged conditions (Wilson, 2005; Michael, 2015). Sulfide minerals that contain sulfuric acid or have the potential to transform it, can have an adverse effect (Fitzpatrick et al., 2008; Michael, 2015). The soils develop due to drainage of pyrite $\left(\mathrm{FeS}_{2}\right)$ parent material (Muhrizal Sarwani, 2013; Masulili, 2015). Soils with such condition can be improved by leachate treatment, to reduce the concentration of toxic compounds such as $\mathrm{Fe}^{2+}, \mathrm{SO}_{4}{ }^{2-}, \mathrm{H}^{+}$, and soil acidity (M. Alwi et al., 2010; Ar-riza et al., 2015). Acid 
sulphate soil contains $\mathrm{FeS}_{2}$ or its products and has been described as strong acidity, its ability to mobilize toxic elements and deoxygenic water systems (Michael, 2015). Cultivation plants in this soil often experience $\mathrm{Fe}^{2+}$ poisoning, organic acids, and $\mathrm{H}_{2} \mathrm{~S}$ (Shamshuddin et al., 2013). Ferro compounds are known as $\mathrm{Fe}$-poisons which can cause a decrease in rice yield of 30-100\%, depending on the level of poisoning and soil fertility (Majerus et al., 2007); (Ar-riza et al., 2015).

Iron can be formed as oxide, sulfide, carbonate, and sulphate (Sahrawat, 2005; M Sarwani et al., 2005; Majerus et al., 2007; Litbang et al., 2013). Iron can be dissolved through the reaction of proteolysis or reduction because of the low redox potential (Warda, 2001; Fink et al., 2016; (Litbang et al., 2013). Iron, in principle, exists as an element in two oxidation states, $\mathrm{Fe}^{3+}$ and $\mathrm{Fe}^{2+}$, which is strongly influenced by environmental conditions (Suduan Gao et al., 2002; Litbang et al., 2013).

Uninterrupted underground water, acid sulphate is benign (Michael, 2015). The beginning of land damage due to oxidation of $\mathrm{FeS}_{2}$, oxidation causes an increases in the concentration of toxic $\mathrm{Fe}^{2+}$ and $\mathrm{S}$ compounds that result in acidification of the soil (Alwi et al., 2010; Ar-riza et al., 2015). Iron toxicity is one of the most common problems in the lowland rice farming system, many swamps and lowlands (rainfed and irrigated lowlands or even mangrove swamps) (Chérif et al., 2009; Nugraha \& Rumanti, 2017). Excessive amounts of $\mathrm{Fe}$ in the soil and in the reduction area is common in soil solutions. This high Fe concentration is attached to the lowland soils (Becker \& Asch, 2005; Chérif et al., 2009), and is the result of massive input of Fe which is insoluble in runoff which is obtained from the ground at a higher altitude (Audebert \& Sahrawat, 2000; Asch et al., 2005; Chérif et al., 2009). Oxidations that cause increased concentrations of poisoning include drought, dug up, or exposed to air by lowering the surface of the water. Sulphides react with $\mathrm{O}$ to form $\mathrm{H}_{2} \mathrm{SO}_{4}$ (Mcgrath et al., 1995; Nordmyr et al., 2008; Michael, 2015). Digging or removing soil or sediments, lowering the surface of ground water or filing lowland soils create this acid (Department of Environment and Conservation, 2011). Oxidation that occurs in a long time will increase the acidity of the land. This condition can cause mineral lattice unsteady, thereby dissolving heavy metals like $\mathrm{Al}, \mathrm{Zn}$, and Cu (Suriadikarta, 2005; Ar-riza et $a l ., 2015)$. The decline in soil quality is not only due to drought, excavation, exposure to the air due to drought, but also caused by human factors when they do not conduct land management system properly and sustainably (Asir et al., 2005; Abdurachman et al., 2005; Las et al., 2006; Dariah et al., 2015). As a result, the land releases $\mathrm{H}_{2} \mathrm{SO}_{4}$ and in turn releases $\mathrm{Fe}^{2+}, \mathrm{Fe}^{3+}, \mathrm{Al}^{3+}$ and other potential toxic elements into soil and water system (Roos \& Astrom, 2005; Nordmyr et al., 2008; Ljung Björklund et al., 2009; Poch et al., 2009; Ljung et al., 2010; Michael, 2015). After acids and toxic element are mobilized, they will cause many ecological effects (Gaviria et al., 1986; Poch et al., 2009; Michael, 2015).

Soil acidity is one of the limiting factors of plant growth in various places, not only in South Kalimantan, especially in Barito Kuala Regency, but also in the world. Serious problems can occur in crop cultivation in acidic soils such as $\mathrm{Al}$ poisoning and low $\mathrm{P}$ concentration (Takita et al., 1999; Zheng et al., 1998; Larsen et al., 1998; Sujana, 2013; Ar-riza et al., 2015). Stunted root growth and problem in absorption of nutrients and water are also found in many research (Jian Feng Ma et al., 2000; Kochian, 1995; Suryana, 2011; Sujana, 2013; Ar-riza et al., 2015). To summarize, acid sulphate soils have the characteristics that when 
oxidized will lower the $\mathrm{pH}$ values to very acidic with negative effects including: (1) decreasing nutrient availability, (2) increasing the impact of toxic elements, (3) decreasing plant yield and affecting the function important soil biota (Sulistiyani et al., 2014; Yuni Aulia Agustina, 2016).

Pyrite accumulates in stagnant soils that contain organic matter and dissolved sulphates derived from sea water. Acid sulphate soils also develop if acid production exceeds the parent material, so the $\mathrm{pH}$ drops to less than 4.0 (Dent, 1986; Masulili, 2015).

Acid sulphate soils react to extreme acids $(\mathrm{pH}<3.5)$ and contain many $\mathrm{SO}_{4}, \mathrm{Fe}^{2+}$, and $\mathrm{Al}^{3+}$. These actual acid sulphate soils are not suitable for agricultural crop (Annisa, 2004; Annisa \& Purwanto, 2010; Hartatik, 2010; Husna, 2014; Dariah et al., 2015; Hartatik et al., 2015; Ar-riza et al., 2015; Gomez, 2016). The high acidity of the soil which causes increased solubility of toxic elements such as $\mathrm{Al}, \mathrm{Fe}$, and $\mathrm{Mg}$ also due to the low base saturation (Hartatik, 2010; Ar-riza et al., 2015; Gomez, 2016). Overcoming the toxic properties arising from $\mathrm{Al}$ can be exchanged by using pyrolysis charcoal called biochar (Goenadi, 2010; Lehmann \& Joseph, 2012).

\section{PHYSICAL, CHEMICAL AND BIOLOGICAL PROPERTIES OF SOIL SULPHATE}

Soil in swamp areas can be included in large groups, namely: (1) alluvial marin soils (Sulfaquent, Sulfaquept Hydraquent, Fluvaquent), (2) alluvial river soils Endoaquent, Endoaquept), and (3) peat soils Haplofibrist/hemist, Sulfihemist/saprist, Sulfohemist/saprist) (USDA, 2010; Haryono, 2013; USDA, 2014b).

The physical properties of soils determine many major soil processes, and the agronomic potential of a soil. The physical, chemical, and biological properties of the soil affect the structure of the soil by providing means to unify soil aggregates. Short-term degradation of soil structure can cause a decrease in water filtration and an increase in erosion. Organic matter plays an important role in aggregation and no organic matter contributes to unstable structure of the soil (Gomez, 2016). Clay minerals influence the physical and chemical soil properties such as swelling ability. Mechanical soil resistance reflects the resistance in the soil against penetration and is related to soil compaction. This resistance increases sharply when the soil dries and related to soil bulk density (Gomez, 2016). Other parameters that reflect the nature of groundwater transmission are the infiltration rate, which is the rate of water flow though the ground surface, and hydraulic conductivity, which is the soil ability to drain water, a very sensitive parameter for groundwater content (Gomez, 2016).

\section{BIOLOGICAL PROPERTIES OF SOIL}

Earthworm activity can increase the filtration rate. It also decreases soil organic matter content due to mineralization. All soil biological properties are interconnected with physical and chemical properties of the soils. Aeration, $\mathrm{SOM}$, and $\mathrm{pH}$ affect the activity of various microorganisms in soils which in turn carry out related reactions in $\mathrm{C}$ and nutrient cycle. Changes in soil properties due to management can influence biological properties in soils and their microbial activity and finally greatly enhanced soil amendments. Soil OM is a key to biological activity and fertility of the soil. Rhizosphere is most important volume of soil where the concentration of $\mathrm{C}$ is suitable for many microorganisms. Organic compounds released by plant roots change the chemical properties of soil and in return greatly increase 
biological activity. Rhizosphere is limited space with intense interaction between plant roots with soil microorganisms. It influence plant development through the production of growth hormones, by reducing the risk of plant diseases, and by increasing nutrients availability (Gomez, 2016).

\section{BIOCHAR}

Soil cleaners nowadays use a lot of biochar (Hartatik et al., 2015). Utilization of biochar as a soil ameliorant has long been done (Goenadi, 2010). Provision of biochar can maintain the availability of ground water (Anita NK, Cahyo $P, 2016)$. Biochar has an average ground water retention capacity of $21.13 \%$ as reported Beck et al. 2011 in (Anita NK, Cahyo P, 2016). Biochar, which is used for a long time, does not disturb the $\mathrm{C} / \mathrm{N}$ balance, is able to hold and make water and nutrients more available to plants. The leaching of $\mathrm{N}$ fertilizer can be significantly reduced by applying the biochar to the planting medium (Steiner, 2009; Goenadi, 2010).

Provision of biochar and $\mathrm{OM}$ can increase $\mathrm{P}$ uptake, also can increase $\mathrm{P}$ availability for plants (Lehmann \& Rondon, 2006; Hartatik et al., 2015; Chairunnisya et al., 2017). Utilization of $\mathrm{OM}$ in the form of biochar is one of the actions to support soil $\mathrm{C}$ conservation (Glaser et al., 2002; Okimori et al., 2003; Dariah et al., 2004; Ogawa et al., 2006); Ogawa \& Okimori, 2010). The Indonesian Biochar Association says that an important characteristic of biochar is a minimum $\mathrm{C}$ content of $20 \%$ (Hartatik et al., 2015).

Biochar as a soil enhancer can improve plant growth by improving soil physical and biological properties (Glaser et al., 2002; Lehmann et al., 2003; Lehmann et al., 2006; Steiner, 2009; Goenadi, 2010). Biochar in soil is a residence or habitat for soil microbes. The increasing nutrient availability for plants is a result of biochar application which in turn can increase nutrient retention and changing soil microbial dynamics (Saleh, 2017).

Biochar application can reduce soil density, $\mathrm{Al}-\mathrm{dd}$ and $\mathrm{Fe}$, as well as increase soil porosity, water content, C-organic, available-P, CEC, and exchangeable-K and Ca (Steiner, 2009; Saleh, 2017). The application of biochar in agricultural soils is useful for (1) increasing the availability of nutrients (2) increasing the ability to retain nutrient and water (Glaser et al., 2002; Liang et al., 2006; Hartatik et al., 2015) (3) creating good habitat for symbiotic microorganisms (Okimori et al., 2003; Ogawa et al., 2006; Ogawa \& Okimori, 2010; Hartatik et al., 2015) (4) increase food crop production (Sukartono et al., 2011; Lehmann et al., 2006; Hartatik et al., 2015 and (5) reduce the rate of $\mathrm{CO}_{2}$ emissions (Laird, 2008; Sohi et al., 2010; Spokas et al., 2012; Hartatik et al., 2015). Biochar given to acid sulphate soils has a positive effect on crop production (Atkinson et al., 2010; Spokas et al., 2012; Hartatik et al., 2015).

Biochar alkalization effect is recommended to increase the $\mathrm{pH}$ of the soil in acidic soils and provide solid OM in the long run. Raw materials and production conditions are two factors that greatly influence biochar physicochemical characteristics (Setiawati et al., 2019).

Soil is largely determined by the texture and nutritional content (Goldin, 1976). Calcification of acid soils is a worldwide practice in agriculture, aims to reduce soil acidity and replenish the positive charge of the soil (Adomaitis et al., 2013; Litvinovich et al., 2017; Holland et al., 2018; Holland et al., 2019; Pavlova et al., 2019).

Calcification will provide the following benefits:

1. Reduce the possibility of $\mathrm{Mn}^{2+}$ and $\mathrm{Al}^{3+}$ toxicity;

2. Increasing microbial activity; 
3. Improve physical condition (soil structure);

4. Increase symbiotic $\mathrm{N}$ fixation by legumes;

5. Increase the delicacy of forage;

6. Provides a cheap source for $\mathrm{Ca}^{2+}$ and $\mathrm{Mg}^{2+}$ when they are lacking at lower $\mathrm{pH}$;

7. Increase the availability nutrients $(\mathrm{P}$ and Mo with the increasing $\mathrm{pH}$ level at 6.0-7.0, but other micronutrients increases when $\mathrm{pH}$ decreases) (USDA, 1999; USDA, 2014a).

Acid sulphate soil conditions ( $\mathrm{pH} 3.5$ ) basalts are expected to dissolve faster (Shazana et al., 2014). Lime ameliorant is commonly used to reduce acidity and $\mathrm{Al}$ toxicity in soils. Amelioration is an effective technology for improving: (a) physical properties (increasing granulation for better aeration), (b) chemical properties (reducing $\mathrm{H}, \mathrm{Fe}, \mathrm{Al}$, and $\mathrm{Mg}$ ions, and increasing the availability of $\mathrm{Mg}$ and $\mathrm{P}$ ), (c) biological properties (increasing microbial activity) (Koesrini et al., 2015). Calcification has a beneficial effect on soil structure because it increases stability of soil structure (Quiroga $e t$ al., 2017).

\section{THE ROLE OF COMPOST ON ACID SULPHATE SOILS}

Composting is the natural process of decomposition of organic material by soil microorganisms (microbes) in a warm, humid, and aerated environment. Waste is collected into piles so that heat that evolves in the process can be saved. As a result, heap temperatures can accelerate the process of degradation of the natural base that occurs slowly in organic waste that falls to the ground. The product of the process is compost or topsoil that is valuable in agriculture for the improvement of the structure and nature of soil moisture and supply plant nutrients because the compost will break down into mineral material (Dalzell et al., 1987).

Soil OM has an important role in improving physical, chemical and biological properties
(Hartatik, 2010; Hartatik et al., 2015). Soil OM is derived from animals and plants remains. It contains $\mathrm{C}, \mathrm{O}$, and $\mathrm{H}$ and various inorganic elements such as N, P, and K. Organic matter can retain a lot of water, even can adsorb up to ten times more nutrients than clay minerals. It is built and broken down in a series of processes. Due to high temperatures in tropical and subtropical areas, the rate of decomposition higher to make SOM content is lower than that of temperate region (Dalzell et al., 1987).

Low level of $\mathrm{pH}$ soils, especially acid sulphate soils, creates the condition with low total microorganisms. Adding organic matter including organic fertilizer to rice plants stimulates microbes into the soil. The microbes in fertilizers enhance plant growth either by supplying essentials nutrients or increasing nutrient availability (Panhwar et al., 2013; Shazana et al., 2014; Safirzadeh et al., 2019).

\section{HISTORY AND USE OF BIOCHAR IN SULPHATE SOIL AGRICULTURE SYSTEMS}

The Amazon River Basin is ignored as a site with little wealth or interest. In 1870, James Orton, an American explorer, noticed that in addition to the normally gray and acidic soil of the basin there were large areas of black and very fertile soil. Researchers were flocking to investigate the mysterious dark earth, or terra preta as local people known. In 1879, naturalist Herbert H. Smith concluded that "the lumpy land owes its wealth to the protection of a thousand kitchens for perhaps a thousand year". This fending, supported by the early $20^{\text {th }}$ century geologist William Katzer analysis of soil composition, which was a mixture of mineral residues, charred plant material, and biodegradable organic matter - started to rotate (Orellana \& International, 2012). 
For many people, this is a silly idea. But for Betty J. Meggers, the famous Smithsonian archeologist has argued that despite the rice flora in the river valleys, a weak Amazonian soil might not be able to sustain the nutrients needed for complex community agriculture needs. $\mathrm{He}$ asserted that every village containing more than 1000 inhabitants collapse (Wayne, 2012).

This terra preta or biochar had been established as a soil amendment and C sequestering agent. The biochar, based on recent research findings, has the potential for liming with a good $\mathrm{pH}$ buffering capacity, so that it has the potential to improve soil acidity. The biochar is also an adsorbent for removing heavy metals or pollutants, and has the capacity to retain water and nutrients, a characteristic that has the potential to reduce the problem of leaching very acidic tropical soils, as well as being a source of nutrients for plant growth. Being a safe habitat for the soil microbial community. Designated as a $\mathrm{C}$ sequestration agent, and reducing the emission of greenhouse gases, making it to become a climate change mitigation tool. The beneficial effect of the use of biochar on acid soils has attracted the attention of researchers around the world and research findings are formulated to be a government policy in several countries (DeLuca et al., 2019). The names of the researchers are as follows:

1. Gao and DeLuca (2016), states that: The number papers published annually about biochar has increased exponentially over the past 20 years.

2. Lehmann and Joseph, (2015), states that: Biochar is produced for soil amendments, while charcoal is generally produced as an energy carrier.

3. Brown et al. (2015), states that: Biochar can be made from a various material including forest and plant residues, community solid waste, or even biosolids.
4. DeLuca et al. (2015b), states that: The characteristics of biochar can also change the hydrological nature of the soil and subsequently affect the transformation of soil nutrients.

5. Atkinson et al. (2010), states that: Biochar is a new topic of interest in science.

6. DeLuca and Aplet, (2008), states that: Biochar is a stable, C-rich material produced from pyrolysis of organic matter in an O-limited environment under controlled conditions and differs from charcoal produced during forest fires.

7. Lehmann et al. (2006), states that: Biochar is rich in nature- $\mathrm{C}$ combined with its unique resistance to decomposition has made it as a way of mitigating climate change when applied to soils.

In spite of the fact that the term biochar was only introduced in nowadays, the initial idea in using charcoal for agricultural purposes has been around for centuries. Amazon dark earth or terra preta soil found in the Amazon River Basin was reported to have been founded by native people thousands of year ago. However, it remains as the most fertile and biodiversityrich soils in the area (DeLuca et al., 2019). The response of soil scientists to the origin of terra preta is unclear and some assumes as below:

1. Glaser and Birk (2012), states that: The charcoal remaining in this soil makes it unlikely that it is a product of burning biomass in slash and burn agriculture. However, it is not clear whether biochar application on purposes or a means of sanitary management in populated areas.

2. Olarieta et al. (2011), states that: It shows that an ancient method named foreigner, a structure that similar to a charcoal furnace, was used in the Mediterranean area to make soil fertilizing material with dry wood until the 1960s. 
3. Ogawa and Okimori, (2010), states that: Pioneer works on the application of biochar in agriculture were in combination with composting has been proven to have been carried out by Japanese farmers since the early twentieth century.

4. Nishio, (1996), states that: Farmers use rice husk and other agricultural residues to produce charcoal using soil furnaces and use it mostly as soil improvement or odor absorber.

5. Saito (1990), states that: Investigation insight into the beneficial effects of biochar on soils received little attention by Japanese scientists until the early 1980 s.

Several papers discussing the use of biochar in agricultural ecosystems (DeLuca et al., 2019) can be seen as below:

1. He et al. (2017), states that: Management of greenhouse gases and emissions.

2. Nguyen et al. (2017), states that: Soil fertility and management of soil nutrients.

3. Griffin et al. (2017), states that: Productivity in plant.

4. Jones et al. (2012), states that: Productivity in plant.

5. Lehmann et al. (2006), states that: Storage and absorption of $\mathrm{C}$ in soils.

The application of biochar in agriculture is a challenge given the variable and possible longterm benefits of biochar. The biochar production distributed by low-tech pyrolysis kilns can increase the attractiveness of biochar to agriculture which produces a small amount of biochar using local resources. This quick production method has been reported to have low greenhouse gas emissions and is widely used in many small scale agricultural (Cornelissen et al., 2016; H DeLuca, 2016; Si Gao \& Deluca, 2016; Si Gao et al., 2017; Pandit et al., 2017; Si Gao \& Deluca, 2018; Hagemann et al., 2018; DeLuca et al., 2019).
Biochar application in agricultural soils can cause interactions that affect the physical properties such as soil porosity, water holding capacity, bulk density, aggregation, and drainage (Lehmann \& Joseph, 2012; DeLuca et al., 2019).

The biochar is very porous and has a large surface area, porosity, and storage capacity of water or nutrients when added to the soil as the research statements about adding biochar to the soil such (DeLuca et al., 2019) as follow:

1. Du et al. (2017), states that: Observed an increase in soil macro-aggregate stability with increasing black charcoal doses.

2. Liu et al. (2017a), states that: Reported $17 \%$ increase in soil porosity and a $28 \%$ increase in groundwater capacity from silt clay farming after the application of corn black charcoal.

3. Liu et al. (2017a), states that: Reduced bulk density mediated by black charcoal can reduce soil compaction and possibly promotion of plant growth.

4. Wang et al. (2017a), states that: Reported a significant increase in the stability of wet aggregate $(126 \%$ and $217 \%)$ in silt clay soils after the application of walnut shell charcoal or softwood black charcoal.

5. Agegnehu et al. (2016a), states that: The addition of black charcoal to the soil leads to the creation of aggregate bridges and empty spaces, therefore reducing soil density.

6. Głąb et al. (2016), states that: The application of wheat straw biochar increased the total porosity of agricultural soils, with the most increasing volume being in small pores (diameter $<50 \mu \mathrm{m}$ ). Changes in soil porosity are also reflected in water retention investigated with finer black charcoal which results in an increase in water holding capacity. 
7. Jones et al. (2011b), states that: The addition of black charcoal to the soil leads to the creation of aggregate bridges and empty spaces, therefore reducing soil density.

8. Ulyett et al. (2014), states that: Black charcoal has also been reported to increase water retention by $1.3 \%$ in clay soils.

\section{HISTORY OF LIME USE IN ACID SULPHATE SOIL}

Lime was used by the Romans 2000 years ago to neutralize the acidity on agricultural land and has been practiced for centuries (Goulding, 2016). Liming of acid soils is a worldwide practice in agriculture (Adomaitis et al., 2013; Litvinovich et al., 2017; Holland et al., 2018; Pavlova et al., 2019) and aims to reduce soil acidity (Pavlova et al., 2019).

Calcification is common management practice and has long been used to maintain optimal $\mathrm{pH}$ for crop production. The opinions of the research experts regarding the use of lime in acid sulphate soils are shown (Holland et al., 2019) as below:

1. Nguyen et al. (2017) states that: Soil fertility and nutrient management.

2. Goulding, (2015) states that: Calcification is a common management practice and has long been used to maintain soil $\mathrm{pH}$ for crop yields.

3. Tunney et al. (2010) states that: Liming is needed for the availability of good nutrients and plat growth in acid soils.

4. Farhoodi and Coventry, (2008) states that: Previous studies successfully quantified the relationship between soil $\mathrm{pH}$ and yield of some fertile plants.

5. Liu et al. (2004 states that: Previous studies successfully quantified the relationship between soil $\mathrm{pH}$ and yield of some fertile plants.
6. Cifu et al., (2004) states that: Most plants are fertile, there is a positive crop response associated with liming. However, there are differences between plants in yield response to lime.

7. Cifu et al., (2004) states that: Depending on the source of lime, the application can increase $\mathrm{Mg}^{2+}$ relative to $\mathrm{Ca}^{2+}$.

8. Chambers and Garwood, (1998) states that: Lime affects the chemical properties of the soil. For example, a decrease in exchangeable-Ca and estimated $\mathrm{CaCO}_{3}$ losses have been estimated.

9. Slattery and Coventry, (1993), states that: Previous studies successfully quantified the relationship between soil $\mathrm{pH}$ and yield of some fertile plants.

10. Haynes, (1982), states that: Calcification changes $\mathrm{P}$ availability and this has implications for $\mathrm{P}$ uptake of plants after the application.

11. Bolton, (1977), states that: Lime affects the chemical properties of the soil. For example, a decrease in exchangeable-Ca and estimated $\mathrm{CaCO}_{3}$ losses have been estimated.

Application of GML (Ground Magnesium Limestone), basalts and biological fertilizers significantly increases plant height, leaf chlorophyll content and rice yield. This might be an effect resulting from an increase in soil $\mathrm{pH}$ which reduces the toxicity of $\mathrm{Al}$ and $\mathrm{Fe}$ (Mardi and Pheng S.K, 2007; Panhwar et al., 2016).

\section{HISTORY OF THE USE OF COMPOST IN SULPHATE SOIL AGRICULTURE}

Organic waste composting has been practiced for centuries by farmers in many parts of the world (Dalzell et al., 1987). Research relating to soil organic fractions can be traced back more than 200 years (Murphy, 2014). Composting is 
the decomposition process of organic material by microorganisms in a warm, humid, and well aerated condition. Waste is collected together into a pile. As a result, the temperature rises and accelerate the degradation of the natural base which usually occurs slowly. The final product of this process is compost or topsoil that is valuable to improve the structure and soil moisture retention and even to supply plant nutrient when compost is finally broken down into minerals (Dalzell et al., 1987).

The properties of soil that are affected by compost have been classified into three major groups: biological, chemical, and physical properties. It should be noted that three are strong interactions and interdependencies between these groups. For example, the ability of compost to multivalent chelate can influence its potential to stabilize soil structure and also its biodegradability (Cork et al., 2012; Murphy, 2014; Ibrahim et al., 2019). Compost is important in soil productivity and quality and greatly influences the physical, chemical, and biological processes of the soil. It is one of the main soil properties that control nutrients in agricultural production systems and is an index of soil productivity (Ibrahim et al., 2019). Soil $\mathrm{OM}$ is formed from animals and plant remains. It contains $\mathrm{C}, \mathrm{O}$, and $\mathrm{H}$ and many inorganic elements such as N, P, and K. Organic matter can retain a lot of moisture and adsorbs more nutrients than clay minerals. Because of high temperatures in tropical and subtropical areas, the rate of loss of SOM is high and it is difficult to maintain (Dalzell et al., 1987; Ibrahim et al., 2019).

\section{CONCLUSIONS}

Biochar alkalization effect is recommended to increase the $\mathrm{pH}$ of the soil in acidic soils and provide solid OM in the long run and have the capacity to retain water and nutrients and become a habitat for soil organisms. Lime as acid amendments can control acidity on agricultural land and its use has been practiced for centuries and continues to the present day. Calcification of acid soils can reduce the acidity to the soil and replenish the positive charge of the soil. Compost is important in soil productivity and quality and greatly influences the physical, chemical, and biological processes of the soil. It is one of the main soil properties that control nutrients in agricultural production systems and is an index of soil productivity.

\section{REFERENCES}

Abdurachman, A., Dariah, A., \& Mulyani, A. (2005). Strategi dan teknologi pengelolaan lahan kering mendukung pengadaan pangan nasional. Jurnal Litbang Pertanian, 98.

Adomaitis, T., Staugaitis, G., Mažvila, J., Vaišvila, Z., Arbačiauskas, J., Lubyte, J., Šumskis, D., \& Švegžda, A. (2013). Leaching of base cations as affected by a forty-year use of mineral fertilisation. Zemdirbyste, $\quad$ 100(2), 119-126. https://doi.org/10.13080/z-a.2013.100.015

Ah, E. N. I. M., \& Nursyamsi, D. (2015). Potensi berbagai bahan organik rawa sebagai sumber biochar Potency of various organic materials from swampland as a source of biochar. Jurnal Balai Penelitian Pertanian Lahan Rawa (Balittra), 1, 776781.

https://doi.org/10.13057/psnmbi/m010417

Alwi, M., Sabiham, S., \& Anwar, S. (2010). Pelindian tanah balandean Kalimantan Selatan pada beberapa kondisi potensial redok menggunakan sumber air insitu. Jurnal Tanah Tropika, 83-94.

Alwi, Muhammad. (2014). Prospek Lahan Rawa Pasang Surut untuk Tanaman Padi. Jurnal Litbang Pertanian, 2007, 45-59. 
Anita NK, Cahyo P, W. (2016). Kajian residu biochar sekam padi, kayu dan tempurung kelapa terhadap ketersediaan air pada tanah lempung berliat. Jurnal Tanah Dan Sumberdaya Lahan, 3(1), 253-260.

Annisa, W. (2004). Retensi p oleh oksida besi di tanah sulfat masam setelah reklamasi lahan. Jurnal Sumberdaya Lahan.

Annisa, W., \& Purwanto, B. H. (2010). Retensi $\mathrm{P}$ oleh oksida besi di tanah sulfat masam setelah reklamasi lahan. Jurnal Sumberdaya Lahan, 4(1), 47-56.

Ar-riza, I., Alwi, M., Tanaman, B., Penelitian, B., Lahan, P., Tanah, K., Penelitian, B., \& Lahan, P. (2015). Peningkatan Hasil Padi di Tanah Sulfat Masam melalui Kombinasi Perlakuan Lindi dan Olah Tanah Combination of Leaching Treatment and Soil Tillage. Jurnal Agronomi Indonesia (Indonesian Journal of Agronomy), 43(2), 105-110.

Arsyad, D. M., Saidi, B. B., \& Enrizal. (2014).

Pengembangan inovasi pertanian di lahan rawa pasang surut mendukung kedaulatan pangan. Jurnal Pengembangan Inovasi Pertanian, 7(4), 169-176.

Asch, F., Becker, M., \& Maccarthy, D. (2005).

A quick and efficient screen for resistance to iron toxicity in lowland rice. Journal of Plant Nutrition and Soil Science, 168, 764773.

https://doi.org/10.1002/jpln.200520540

Asir, L. O., Teknik, A., Lahan, R., Pada, T., \& Asir, L. O. (2005). LAHAN BEKAS GALIAN INDUSTRI ( Alternative Rehabilitation Technique on ex-Industrial Land ) plasma sistem tata air kontribusinya terhadap perbaikan lahan-lahan kritis di Indonesia . Ini penanggulangan lahan kritis , hal ini ditandai dengan telah berlangsun. Jurnal Sumberdaya Lahan, 113-130.

Atkinson, C., Fitzgerald, J., \& Hipps, N. (2010). Potential Mechanisms for Achieving
Agricultural Benefits from Biochar Application to Temperate Soils: A Review. Plant and Soil, 337, 1-18. https://doi.org/10.1007/s11104-010-0464-5 Audebert, A., \& Sahrawat, K. (2000). Mechanisms for Iron Toxicity Tolerance in Lowland Rice. Journal of Plant Nutrition, 23 , 1877-1885. https://doi.org/10.1080/0190416000938215 0

Becker, M., \& Asch, F. (2005). Iron toxicity in rice - Conditions and management concepts. Journal of Plant Nutrition and Soil Science, 168(4), 558-573. https://doi.org/10.1002/jpln.200520504

Berek, A. K. (2019). The potential of biochar as an acid soil amendment to support Indonesian food and energy security - A review. Pertanika Journal of Tropical Agricultural Science, 42(2), 745-759.

Chairunnisya, R. A., Hanum, H., \& Hidayat, B. (2017). Aplikasi Bahan Organik dan Biochar untuk Meningkatkan C - Organik, $\mathrm{P}$ dan $\mathrm{Zn}$ tersedia Pada Tanah Sawah. Jurnal Tanah Dan Iklim, 5(3), 494-499.

Chérif, M., Audebert, A., Fofana, M., \& Zouzou, M. (2009). Evaluation of Iron Toxicity on Lowland Irrigated Rice in West Africa. Tropicultura, 27(2), 88-92.

Cork, S., Eadie, L., Mele, P. M., Price, R., \& Yule, D. (2012). The relationships between land management practices and soil condition and the quality of ecosystem services delivered from agricultural land in Australia. Book, September, 127.

Cornelissen, G., Pandit, N. R., Taylor, P., Pandit, B. H., Sparrevik, M., \& Schmidt, H. P. (2016). Emissions and char quality of flame-curtain "Kon Tiki" kilns for farmerscale charcoal/biochar production. PLoS ONE, $11(5), \quad 1-16$. https://doi.org/10.1371/journal.pone.01546 17 
Dalzell, H. ., Biddelstone, A. J., Gray, K. R., \& Thuraniranjan, K. (1987). Soil managment: compost production and use in tropical and subtropical environments. Coletin 56 de Suelos de La FAO, 6.6, 134.

Dariah, A., Nurida, neneng laila, \& Jubaedah. (2004). Pemanfaatan Pembenah Tanah untuk Pemulihan Tanah Terdegradasi yang Didominasi Fraksi Pasir dan Liat. Litbang Pertanian, 669-676.

Dariah, A., Sutono, S., Nurida, N. L., Hartatik, W., \& Pratiwi, E. (2015). Pembenah Tanah untuk Meningkatkan Produktivitas Lahan Pertanian. Jurnal Sumberdaya Lahan, 9(2), 67-84.

DeLuca, T., Farming, S. G.-O., \& 2019, undefined. (2019). Use of Biochar in Organic Farming. Springer, August. https://doi.org/10.1007/978-3-030-04657-6

Dent, D. (1986). Acid sulphate soils: a baseline for research and development. Acid Sulphate Soils: A Baseline for Research and Development.

Department of Environment and Conservation. (2011). Treatment and management of soils and water in acid sulphate soil landscapes (Issue June). http://www.der.wa.gov.au/images/documen ts/your-environment/acid-sulphatesoils/guidelines/ass-managementguideline.pdf

Eka Bhakari, H., \& Hanum, H. (2013). Pengaruh Pemberian Kompos Jerami dan Pupuk SP-36 pada Tanah Sulfat Masam Potensial terhadap Perubahan Ssifat Kimia serta Pertumbuhan dan Produksi Padi (Oriza sativa L.). 2(1), 2337-6597.

Fink, J. R., Inda, A. V., Tiecher, T., \& Barrón, V. (2016). Iron oxides and organic matter on soil phosphorus availability. Ciencia $e$ Agrotecnologia, 40(4), 369-379. https://doi.org/10.1590/141370542016404023016
Fitzpatrick, R., Grealish, G., Shand, P., Marvanek, S., Thomas, B., Creeper, N., Merry, R., \& Raven, M. (2008). Information paper on risk assessment of acid sulphate soil materials in the Currency Creek, Finniss River, Tookayerta Creek and Black Swamp Region, South Australia. Csiro, January, 1-13.

Gao, Si, \& Deluca, T. (2016). Influence of biochar on soil nutrient transformations, nutrient leaching, and crop yield. Advances in Plants \& Agriculture Research, 4, 150. https://doi.org/10.15406/apar.2016.04.0015 0

Gao, Si, \& Deluca, T. (2018). Wood biochar impacts soil phosphorus dynamics and microbial communities in organicallymanaged croplands. Soil Biology and Biochemistry, https://doi.org/10.1016/j.soilbio.2018.09.00 2

Gao, Si, Hoffman-Krull, K., \& Deluca, T. (2017). Soil biochemical properties and crop productivity following application of locally produced biochar at organic farms on Waldron Island, WA. Biogeochemistry, 136, 31-46. https://doi.org/10.1007/s10533017-0379-9

Gao, Suduan, Tanji, K., Scardaci, S., \& Chow, A. (2002). Comparison of Redox Indicators in a Paddy Soil during Rice-Growing Season. Soil Science Society of America Journal - SSSAJ, 66. https://doi.org/10.2136/sssaj2002.0805

Gaviria, J., Schmittou, H., \& Grover, J. (1986). Acid sulphate soils: Identification, formation and implications for aquaculture. Journal of Aquaculture in the Tropics, 1, 99-109.

Glaser, B., Lehmann, J., \& Zech, W. (2002). Ameliorating physical and chemical properties of highly weathered soils in the tropics with charcoal - a review. Biology 
and Fertility of Soils, 35(4), 219-230. https://doi.org/10.1007/s00374-002-0466-4

Goenadi, L. P. S. dan D. H. (2010). Pemanfaatan bio-char sebagai pembawa mikroba untuk pemantap agregat tanah Ultisol dari Taman Bogo-Lampung. Jurnal Balai Penelitian Bioteknologi Perkebunan, 78(2), 52-60.

Goldin, A. (1976). ScholarWorks at University of Montana Effects of limestone soils on plant distribution in the Garnet Mountains , Montana Let us know how access to this document benefits you . Dissertations and Profesional Papers.

Gomez, A. (2016). The Soil . Physical , Chemical and Biological Properties. Journal of Tropical Soils, 15-27. https://doi.org/10.1007/978-3-319-46116-8

Goulding, K. W. T. (2016). Soil acidification and the importance of liming agricultural soils with particular reference to the United Kingdom. Soil Use and Management, 32(3), 390-399.

https://doi.org/10.1111/sum.12270

H DeLuca, T. (2016). Influence of Biochar on Soil Nutrient Transformations, Nutrient Leaching, and Crop Yield. Advances in Plants \& Agriculture Research, 4(5). https://doi.org/10.15406/apar.2016.04.0015 0

Hagemann, N., Subdiaga, E., Orsetti, S., De la Rosa, J., Knicker, H., Schmidt, H.-P., Kappler, A., \& Behrens, S. (2018). Effect of biochar amendment on compost organic matter composition following aerobic composting of manure. Science of The Total Environment, 613-614, 20-29. https://doi.org/10.1016/j.scitotenv.2017.08. 161

Hartatik, W. (2010). Karakteristik dan Teknologi Pengolahan Lahan Sulfat Masam Mendukung Pertanian Ramah Lingkungan. Jurnal Balitbangta, 1986.
Hartatik, W., Wibowo, H., \& Purwani, J. (2015). Aplikasi Biochar dan Tithoganic dalam Peningkatan Produktivitas Kedelai (Glycine max L.) pada Typic Kanhapludults di Lampung Timur. Jurnal Tanah Dan Iklim, 39(1), 51-62. https://doi.org/10.2017/jti.v39i1.6220

Haryono, B. (2013). Lahan Rawa Penelitian dan Pengembangan (Noor/Balittra (ed.); 13th ed.).

Holland, J. E., Bennett, A. E., Newton, A. C., White, P. J., McKenzie, B. M., George, T. S., Pakeman, R. J., Bailey, J. S., Fornara, D. A., \& Hayes, R. C. (2018). Liming impacts on soils, crops and biodiversity in the UK: A review. Science of the Total Environment, 610-611(August), 316-332. https://doi.org/10.1016/j.scitotenv.2017.08. 020

Holland, J. E., White, P. J., Glendining, M. J., Goulding, K. W. T., \& McGrath, S. P. (2019). Yield responses of arable crops to liming - An evaluation of relationships between yields and soil $\mathrm{pH}$ from a longterm liming experiment. European Journal of Agronomy, 105(May), 176-188. https://doi.org/10.1016/j.eja.2019.02.016

Husna, N. (2014). Pengelolaan Bahan Organik Di Tanah Sulfat Masam Organic Matter Mangement in Acid Sulphate Soil. Prosiding Seminar Nasional Lahan Suboptimal, 1(13), 979-587.

Ibrahim, M., Ghanem, F., Al-Salameen, A., \& Al-Fawwaz, A. (2019). The Estimation of Soil Organic Matter Variation in Arid and Semi-Arid Lands Using Remote Sensing Data. International Journal of Geosciences, 10(05), 576-588. https://doi.org/10.4236/ijg.2019.105033

Jian Feng Ma, Taketa, S., \& Zhen Ming Yang. (2000). Aluminum tolerance genes on the short arm of chromosome $3 \mathrm{R}$ are linked to organic acid release in triticale. Plant 
Physiology, 122(3),

687-694.

https://doi.org/10.1104/pp.122.3.687

Kochian, L. V. (1995). Cellular mechanisms of aluminum toxicity and resistance in plants. Annual Review of Plant Physiology and Plant Molecular Biology, 46(0066), 237260.

https://doi.org/10.1146/annurev.pp.46.0601 95.001321

Koesrini, ., William, E., \& Nursyamsi, D. (2015). Application of Lime and Adaptable Variety to Increase Tomato Productivity at Potential Acid Sulphate Soil. Journal of Tropical Soils, 19(2), 59-66. https://doi.org/10.5400/jts.2014.v19i2.5966

Laird, D. A. (2008). The charcoal vision: A win-win-win scenario for simultaneously producing bioenergy, permanently sequestering carbon, while improving soil and water quality. Agronomy Journal, $100(1)$, 178-181. https://doi.org/10.2134/agronj2007.0161

Larsen, P. B., Degenhardt, J., Tai, C. Y., Stenzler, L. M., Hovvell, S. H., \& Kochian, L. V. (1998). Aluminum-resistant arabidopsis mutants that exhibit altered patterns of aluminum accumulation and organic acid release from roots. Plant Physiology, 117(1), 9-18. https://doi.org/10.1016/13695266(88)80022-0

Las, I., Subagyono, K., \& Setiyanto, A. P. (2006). Isu dan Pengelolaan Lingkungan dalam Revitalisasi Pertanian. Pertanian, 25(3).

Lehmann, J., Gaunt, J., \& Rondon, M. (2006). Bio-char sequestration in terrestrial ecosystems - A review. Mitigation and Adaptation Strategies for Global Change, 11(2), 403-427. https://doi.org/10.1007/s11027-005-9006-5
Lehmann, J., \& Joseph, S. (2012). Biochar for environmental management: An introduction. In Biochar for Environmental Management: Science and Technology. https://doi.org/10.4324/9781849770552

Lehmann, J., \& Rondon, M. (2006). Bio-Char Soil Management on Highly Weathered Soils in the Humid Tropics. Book, 517-529. https://doi.org/10.1201/9781420017113.ch3 6

Lehmann, J., Silva Junior, J., Steiner, C., Nehls, T., Zech, W., \& Glaser, B. (2003). Nutrient availability and leaching in an archaeological Anthrosol and a Ferralsol of the Central Amazon basin: Fertilizer, manure and charcoal amendments. Plant and Soil, 249, 343-357. https://doi.org/10.1023/A:1022833116184

Liang, B., Lehmann, J., Solomon, D., Kinyangi, J., Grossman, J., O’Neill, B., Skjemstad, J. O., Thies, J., Luizão, F. J., Petersen, J., \& Neves, E. G. (2006). Black Carbon Increases Cation Exchange Capacity in Soils. Soil Science Society of America Journal, 70(5), 1719-1730. https://doi.org/10.2136/sssaj2005.0383

Litbang, B., Penelitian, B., Lahan, P., Karet, J. K., \& Utara, L. (2013). Dinamika Besi pada Tanah Sulfat Masam yang Ditanami Padi. Jurnal Balai Penelitian Pertanian Lahan Rawa (Balittra), 67-75.

Litvinovich, A., Pavlova, O., Lavrishchev, A., Bure, V., \& Saljnikov, E. (2017). Huminių rūgščių ir humino transformacijų Umbric Albeluvisol Abruptic empirinis modelis, priklausomai nuo dirvožemio kalkinimo. Zemdirbyste, 104(2), 115-122. https://doi.org/10.13080/z-a.2017.104.015

Ljung Björklund, K., Maley, F., Cook, A., \& Weinstein, P. (2009). Acid sulphate soils and human health-A Millennium Ecosystem Assessment. Environment International, $\quad 35, \quad 1234-1242$. 
https://doi.org/10.1016/j.envint.2009.07.00 2

Ljung, K., Maley, F., \& Cook, A. (2010). Canal estate development in an acid sulphate soilimplications for human metal exposure. Landscape and Urban Planning, 97(2), 123-131.

https://doi.org/10.1016/j.landurbplan.2010. 05.003

Majerus, V., Bertin, P., \& Lutts, S. (2007). Effects of iron toxicity on osmotic potential, osmolytes and polyamines concentration in the African rice (Oryza glaberrima Steud). Plant Science - PLANT SCI, 173, 96-105. https://doi.org/10.1016/j.plantsci.2007.04.0 03

Mardi dan Pheng S.K. (2007). Management of Acid Sulphate Soils for Sustainable Rice Cultivation in Malaysia.

Masulili, A. (2010). Rice Husk Biochar for Rice Based Cropping System in Acid Soil 1 . The Characteristics of Rice Husk Biochar and Its Influence on the Properties of Acid Sulphate Soils and Rice Growth in West Kalimantan , Indonesia. Journal of Agricultural Science, 39-47.

Masulili, A. (2015). Pengelolaan lahan sulfat masam untuk pengembangan pertanian. Jurnal Agrosans, 12, 1-13.

Mcgrath, S., Chaudri, A., \& Giller, K. (1995). Long-Term Effects of Metals in Sewage Sludge on Soils, Microorganisms and Plants. Journal of Industrial Microbiology, 14 , 94-104. https://doi.org/10.1007/BF01569890

Michael, P. S. (2015). Ecological Impacts and Management of Acid Sulphate Soil: A Review. Journal Asian: Water, Environment and Pollution, March.

Murphy, B. W. (2014). Soil Organic Matter and Soil Function - Review of the Literature and Underlying Data. Journal of Environmental Quality, May.

Nordmyr, L., Astrom, M., \& Peltola, P. (2008). Metal pollution of estuarine sediments caused by leaching of acid sulphate soils. Estuarine, Coastal and Shelf Science, 76, 141-152.

https://doi.org/10.1016/j.ecss.2007.07.002

Nugraha, Y., \& Rumanti, A. (2017). Perakitan Varietas Padi Toleran Keracunan Besi Breeding for Rice Variety Tolerant to Iron Toxicity. Jurnal Iptek Tanaman Pangan, 12(1), 9-24.

Ogawa, M., \& Okimori, Y. (2010). Pioneering works in biochar research, Japan. Australian Journal of Soil Research, 48(67), 489-500.

https://doi.org/10.1071/SR10006

Ogawa, M., Okimori, Y., \& Takahashi, F. (2006). Carbon Sequestration by Carbonization of Biomass and Forestation: Three Case Studies. Mitigation and Adaptation Strategies for Global Change, 11. https://doi.org/10.1007/s11027-0059007-4

Okimori, Y., Ogawa, M., \& Takahashi, F. (2003). Potential of CO2 emission reductions by carbonizing biomass waste from industrial tree plantation in South Sumatra, Indonesia. Mitigation and Adaptation Strategies for Global Change, 8 , 261-280. https://doi.org/10.1023/B:MITI.000000564 $3.79908 .5 \mathrm{a}$

Orellana, F. De, \& International, P. (2012). Conquistadors, cannibals and climate change A brief history of biochar. Journal of Conservation, June.

Pandit, N. R., Mulder, J., Hale, S. E., Schmidt, H. P., \& Cornelissen, G. (2017). Biochar from "Kon Tiki" flame curtain and other kilns: Effects of nutrient enrichment and kiln type on crop yield and soil chemistry. 
PLoS ONE, 12(4), 1-18.

https://doi.org/10.1371/journal.pone.01763 78

Panhwar, Q., Naher, U., Shamshuddin, J., Othman, R., \& Hakeem, K. (2016). Management of Acid Sulphate Soils for Sustainable Rice Cultivation in Malaysia. In Book. https://doi.org/10.1007/978-3-31934451-5_4

Panhwar, Q., Othman, R., Naher, U., A Rahman, Z., Razi, M. I., \& Shamshuddin, J. (2013). Effect of phosphate-solubilizing bacteria and oxalic acid on phosphate uptake from different $P$ fractions and growth improvement of aerobic rice using 32P technique. Australian Journal of Crop Science, 7, 1131-1140.

Pavlova, O., Litvinovich, A., Lavrishchev, A., Bure, V., \& Saljnikov, E. (2019). Eluvial losses of $\mathrm{Ca}$ from Umbric Albeluvisols Abruptic produced by different doses of lime: Column experiment. Zemljiste $i$ Biljka, 68(1), 1-12. https://doi.org/10.5937/zembilj1901001p

Poch, R., Thomas, B., Fitzpatrick, R., \& Merry, R. (2009). Micromorphological evidence for mineral weathering pathways in a coastal acid sulphate soil sequence with Mediterranean-type climate, South Australia. Soil Research, 47. https://doi.org/10.1071/SR07015

Quiroga, M. J., Olego, M. Á., Sánchez-García, M., Medina, J. E., Visconti, F., Coque, J. J. R., \& Jimeno, J. E. G. (2017). Effects of liming on soil properties, leaf tissue cation composition and grape yield in a moderately acid vineyard soil. Influence on must and wine quality. Oeno One, 51(4), 342-362. https://doi.org/10.20870/oenoone.2017.51.4.2039

Rina, Y., \& Haris, D. (2013). Zona kesesuaian lahan rawa pasang surut berbasis keunggulan kompetitif komoditas. Jurnal
Balai Penelitian Pertanian Lahan Rawa (Balittra), 10(1), 103-117.

Roos, M., \& Astrom, M. (2005). Hydrochemistry of rivers in an acid sulphate soil hotspot area in western Finland. Agricultural and Food Science AGR FOOD SCI, 14, 24-33. https://doi.org/10.2137/1459606054224075

Safirzadeh, S., Chorom, M., \& Enayatizamir, N. (2019). Effect of phosphate solubilising bacteria (Enterobacter cloacae) on phosphorus uptake efficiency in sugarcane (Saccharum officinarum L.). Soil Research, 57. https://doi.org/10.1071/SR18128

Sahrawat, K. (2005). Iron Toxicity in Wetland Rice and the Role of Other Nutrients. Journal of Plant Nutrition - J PLANT NUTR, 27 , 1471-1504. https://doi.org/10.1081/PLN-200025869

Saleh, M. (2017). Pengujian Formulasi Biofertilizer pada Tanaman Padi di Lahan Pasang Surut. Prosiding Seminar Nasional Lahan Basah, 916-920.

Sarwani, M, Shamshuddin, J., Ishak, C., \& Husni, H. (2005). Changes in iron-poor acid sulphate soil upon submergence. Geoderma, 131. https://doi.org/10.1016/j.geoderma.2005.03. 006

Sarwani, Muhrizal. (2013). Karakteristik Dan Potensi Lahan Sub Optimal Untuk Pengembangan Pertanian Di Indonesia. Jurnal Penelitian Pertanian Tanaman Pangan, $7(1)$. https://doi.org/10.2018/jsdl.v7i1.6429

Setiawati, E., Prijono, S., Mardiana, D., Annisa, W., \& . S. (2019). Effects of Durian Wood Waste Biochar on Acid Sulphate Soil Properties and Rice Yield in Indonesia. Journal of Agronomy, 18(2), 71-79. https://doi.org/10.3923/ja.2019.71.79

Shamshuddin, J., Elisa, A. A., Shazana, M. A. R. S., \& Fauziah, I. C. (2013). Rice defense 
mechanisms against the presence of excess amount of $\mathrm{Al} 3+$ and $\mathrm{Fe} 2+$ in the water. Australian Journal of Crop Science, 7(3), 314-320.

Shazana, M. A. R., Shamshuddin, J., Fauziah, C. I., Panhwar, Q. A., \& Naher, U. A. (2014). Effects of applying ground basalt with or without organic fertilizer on the fertility of an acid sulphate soil and growth of rice. Malaysian Journal of Soil Science, 18, 87-102.

Sohi, S., Krull, E., Lopez-Capel, E., \& Bol, R. (2010). A Review of Biochar and Its Use and Function in Soil. Advances in Agronomy, 105, 47-82.

Spokas, K. A., Cantrell, K. B., Novak, J. M., Archer, D. W., Ippolito, J. A., Collins, H. P., Boateng, A. A., Lima, I. M., Lamb, M. C., McAloon, A. J., Lentz, R. D., \& Nichols, K. A. (2012). Biochar: A Synthesis of Its Agronomic Impact beyond Carbon Sequestration. Journal of Environmental Quality, 41(4), 973-989. https://doi.org/10.2134/jeq2011.0069

Steiner, C. (2009). Soil Charcoal Amendements Maintain Soil Fertility and Establish a Carmon Sink-Research and Prospects. Journal Soil Ecology Reserch Developments, 125(June), 438-452.

Sujana, I. P. (2013). Peningkatan Produksi Padi pada Tanah Masam dan Upaya Mengatasi Kegagalan Panen dengan Pemberian biochar (Makalah ini disampaikan pada Seminar Nasional / Tema :Reorientasi Riset untuk Mengoptimalkan Produksi dan Rantai Nilai Komoditas Pertanian / 13 April. Siminar Nasional: Reorentasi Riset Untuk Mengoptimalkan Produksi Dan Rantai Nilai Komoditas Pertanian, April.

Sukartono, Utomo, W. H., Kusuma, Z., \& Nugroho, W. H. (2011). Soil fertility status, nutrient uptake, and maize (Zea mays L.) yield following biochar and cattle manure application on sandy soils of Lombok, Indonesia. Journal of Tropical Agriculture, 49, 47-52.

Sulistiyani, D., Imanudin, M., \& Napoleon, A. (2014). PENILAIAN KUALITAS TANAH PADA LAHAN RAWA PASANG SURUT UNTUK TANAMAN JAGUNG (Zea mays L) DI DESA BANYU URIP KECAMATAN TANJUNG. , Palembang 16-17 ..., September, 812-820. http://eprints.unsri.ac.id/6637/

Suriadikarta, D. (2005). Pengelolaan lahan sulfat masam untuk usaha pertanian. Jurnal Litbang Pertanian, 24(98), 1-13. http://pustaka.litbang.pertanian.go.id/publik asi/p3241055.pdf

Suryana, S. dan. (2011). Perbaikan Sifat Fisik dan Kimia Tanah Sawah Tadah Hujan Melalui Pemberian Biochar dalam Upaya Meningkatkan Produktivitas Lahan. Jurnal Tanah Dan Iklim, 1-5.

Takita, E., Koyama, H., \& Hara, T. (1999). Organic acid metabolism in aluminumphosphate utilizing cells of carrot (Daucus carota L.). Plant and Cell Physiology, 40(5), 489-495. https://doi.org/10.1093/oxfordjournals.pcp. a029569

UNICEF. (2013). Laporan Tahunan Kementrian Pertanian 2017. Buletin Jendela Data Dan Informasi Kesehatan, 29-33.

USDA: (2010). Keys to Soil Taxonomy. Book. USDA. (1999). Liming To Improve Soil Quality in Acid Soils. Soil Quality - Agronomy Technical Note No. 8. Book, 8, 1-6. http://soils.usda.gov/sqi/management/files/s q_atn_8.pdf\%5Cnhttp://workspace.bananah ill.net/library/Soil/Acidification/1999_USD

A_Liming_acid_soils.pdf

USDA. (2014a). Keys to Soil Taxonomy, 12th ed. Change, 12, 327-328. 
USDA. (2014b). Keys to soil taxonomy. Soil Conservation Service, 12, 410. https://doi.org/10.1109/TIP.2005.854494

Warda. (2001). Painting the Rice Red: Iron Toxicity in the Lowlands. Physiologist, 2937.

Wayne, E. (2012). Conquistadors , cannibals and climate change A brief history of biochar. Journal of Conservation, June, 5.

Wilson, B. (2005). Elevations of sulfurous layers in acid sulphate soils: What do they indicate about sea levels during the Holocene in eastern Australia? Catena, 62, 45-56. https://doi.org/10.1016/j.catena.2005.02.00 2

Yuni Aulia Agustina, N. S. P. dan B. J. P. (2016). Pengaruh Biochar Dari Limbah Sekam Padi Dan Tandan Kelapa Sawit Terhadap Sifat Kimia Tanah Sulfat Masam. Jurnal Pertanian, 1-15.

Zheng, S. J., Ma, J. F., \& Matsumoto, H. (1998). High aluminum resistance in buckwheat: I. Al-induced specific secretion of oxalic acid from root tips. Plant Physiology, 117(3), 745-751. https://doi.org/10.1104/pp.117.3.745 